\title{
居住者の環境調整行動を考慮した温熱性能評価方法 THERMAL PERFORMANCE EVALUATION METHOD CONSIDERING RESIDENTS' ADJUSTMENT ACTIONS TO THE THERMAL ENVIRONMENT
}

\author{
深澤たまき*, 須 永修通** \\ Tamaki FUKAZAWA and Nobuyuki SUNAGA
}

\begin{abstract}
In the evaluation method for houses, especially for passive and low energy house, should be considered the residents' behaviors and the adjustment actions, such as the resident's movement between rooms, changing clothes and opening or closing windows.

In this paper a thermal performance evaluation method considering the residents' behaviors and actions is proposed. First, the fluctuation comfort zones are illustrated, then the flow of the thermal performance evaluation method using the fluctuation comfort zones is mentioned, and finally, the validity of this evaluation method is shown by the concrete evaluation examples.
\end{abstract}

Keywords : Passive and low energy house, evaluation method, comfort range, adjustment action, natural air temperature 環境共生住宅、評価法、快適範囲、環境調整行動、自然室温

1.はじめに

近年、環境共生建築のさらなる性能向上をめざし、環境共生手法 の開発、温熱環境性能の実測評価およびシミュレーション解析など、 多くの研究がなされている。これらの性能を吟味する際に、一般的 に室内温熱環境とエネルギー消費量の両面から評価されているが、 何を主眼にして評価するかが重要である。

最近の空調設備を用いた場合の性能評価研究では、人間の温冷感、 生理反応を用いて詳細に評価することが提案されている。例えば、

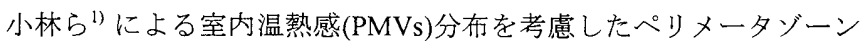
の快適性と省エネルギー評価方法、加藤ら ${ }^{2)}$ による室内空調システ ム制御を組み込んだ CFDを用いて、人体に作用する作用温度を一定 としながら異なる空調システムを比較・評価する方法、山室ら゙)によ る $65 \mathrm{MN}$ モデルとCFDを連成し、空調設備による人体冷却効果を評 価する方法、大森ら (5) $^{5}$ による JOS モデルと CFDを連成し、人体温 熱生理反応によって暖房システムを評価する方法などがある。

一方、住宅に関しては人間の温冷感を用いて評価された例は少な く、一般的に空調負荷やエネルギー消費量により評価されている。 しかし、空調設備を使用しないでも建築手法を適切に組合せること で快適に暮らすことのできる住宅を目指ずべき環境共生住宅におい ては、居住者の温熱環境面から評価する必要があると考えられる。
この観点から、佐藤ら゙) はPMV を指標とした許容環境条件(夏季·冬 季×朝・夜)を設定し、自然室温が許容域を満たす時間を許容時間率 として日本各地の $\mathrm{RC}$ 造戸建住宅の熱性能を評価した。夜間断熱戸、 換気等による建物性能の変更を含めて、居間を主とした室の熱環境 の違いを評価している。

筆者らは、温熱環境面から環境共生住宅を評価する場合には、(1) 居住者のとる環境調整行動の違い、(2)居住者のライフスタイル(室間 移動·室の使用時間)の違い、などを含める必要があると考える。す なわち、居住者の在室時間にその室が居住者の要求をどの程度満た す温熱環境であるかを評価することがより的確であると考えた。ま た、環境共生住宅の普及のためには、住宅を作る設計者・住宅で過ご す居住者に解りやすい指標(空気温度、快適時間)を用いた評価結果 で示すことも重要であると考えた。そこで本研究では、居住者の生 活スケジュール(室の移動)をもとに各室の環境から居住者の曝露環 境を合成し、合成した曝露環境を居住者の条件(代謝量、着衣量許容 幅、許容気流速度)に合わせて評価する方法を提案する。本評価方法 は、住宅以外の一般的な建物、既存建物にも適用できるが、基本設 計段階において、建築的手法の組合せを居住者の条件、生活を考慮 しながら評価、検討に用いることも意図している。

本報ではまず、居住者の条件(生活スケジュール、着衣量許容範囲、

\footnotetext{
本研究は'05年度に日本建築学会学術講演会に扔ける既発表論文 ${ }^{1920)}$ を基に加筆・修正し，まとめたものである。

首都大学東京工学研究科建築学専攻 博士課程 ·工修 Grad. Student, Dept. of Architecture and Building Engineering, Grad. School of Urban ** 首都大学東京都市環境科学研究科建築学専攻 教授 $\cdot$ 工博

Environmental Sciences, Tokyo Metropolitan University, M. Eng. Prof., Dept. of Architecture and Building Engineering, Grad. School of Urban Environmental Sciences, Tokyo Metropolitan Úniversity, Dr. Eng.
} 
許容気流速度)により変動する快適範囲を示し、変動する快適範囲を 使用して、居住者の生活スケジュールに伴う代謝量の変化や環境調 整行動(開口部の開閉、着衣量による調整)を含めて評洒する方法を 提案する。次に、提案した温熱性能評価方法を用いて、評価する居 住者側の条件を变えて戸建モデルを評価し、本評価方法を具体的に 示すとともに、居住者の条件による評価の違いを示し、提案する温 熱性能評価方法の有効性を示す。

\section{2. 居住者の条件による変動快適範囲}

\section{1. 快適範囲の拡張}

現在一般的に使用されている ASHRAE 快適範囲》を居住者の条件 により変動する快適範囲(以後変動快適範团) とする。ASHRAE 快適 範囲で通常固定パラメータとして与えられる居住者の条件を変動パ ラメータとして扱うことで、変動快適範囲に居住者の条件を反映す る。図 1 にSET*の要素と本研究で居住者の条件として扱う変動パラ メータとの関係を示す。また、表 1 に ASHRAE 快適範囲と変動快適 範囲の要件を示す。居住者側の条件である代謝量は居住者の生活ス ケジュールに準じるものとし、着衣量は居住者の着衣量許容範囲、 気流速度は変動するが、居住者の許容気流速度による制限を加えた。 また、湿度条件による不快感を除外するため、ASHRAE 快適範囲に おける露点温度は $2.0\left[{ }^{\circ} \mathrm{C}\right]$ 以上、夏季の条件である湿球温度 $\left.20{ }^{\circ} \mathrm{C}\right]$ 以 下、さらに相対湿度 90[\%]以下の条件を加えた。

図 2 に変動快適範囲への変換手順を示す。まず居住者の条件によ り変化させるために ASHRAEで規定されている ET*による快適域(以 後 $\mathrm{ET} *$ *快適域)を $\mathrm{SET}$ *による快適域(以後 $\mathrm{SET}^{*}$ *快適域)に変換する。 次に、設計者および居住者自身による快適範囲の理解・快適範囲を用 いての評価を容易にするためにSET*快適域を各居住者の条件の空気 温度による快適域(以後 空気温度快適域)に変換する。空気温度快適 域を相対湿度ごとに求め、表 1 に示す変動快適範囲の要件を付加す ることで、居住者の条件による変動快適範囲に変換する。

\section{2. 変動快適範囲への変換条件}

表 2 に快適範囲を変換する際の計算範囲と計算間隔を示す。放射 温度 $=$ 空気温度とし、居住者の条件による変動パラメータとして扱 う気流速度は $1.0\left[\mathrm{~m} / \mathrm{s}\right.$ ]まで、着衣量 ${ }^{8) 9)}$ は $0.3[\mathrm{clo}]($ 半袖十短パン)から 1.2[clo](長袖シャツ+セーター十長ズボン)までとした。計算間隔は 気流速度 $0.1[\mathrm{~m} / \mathrm{s}]$ 、着衣量 $0.1[\mathrm{clo}$ ]とした。ただし、冬季の睡眠時は 蒲団分の着衣量も考虑するために $3.0[\mathrm{clo}]$ を上限とした。また、生活 行為に関しては空気謂和・衛生工学会の標準スケジュールは早11)に基づ き、表 3 に居住者の生活行為と代謝量の関係を示す。

\section{3. 快適範囲の作成方法}

\subsection{1. $\mathrm{ET}^{*}$ 快適域から $\mathrm{SET}^{*}$ 快適域への变換}

図3に表 2 の計算条件で算出した ET*/SET*の散布図とその近似直 線を示す。近似直線が $\mathrm{ET}$ *快適域(平均放射温度=空気温度、相対湿 度 : $50[\%]$ 、代謝量 : $1.1[\mathrm{Met}] 、$ 気流速度 $: 0.15[\mathrm{~m} / \mathrm{s}$ ]、着衣量 :0.5[clo](夏 季) $0.9[\mathrm{clo}]$ (冬季))の範囲内となる SET*を SET*快適域とした。

\subsection{2. 人の条件による違いの検討}

厚生省保健医療局の調查 ${ }^{12}$ をもとに、人の条件(年齢・性別・体格・ 代謝量)による違いの検討を行った。体表面積は日本人の体格に対応 している藤本・渡辺の $(1)$ 式 ${ }^{13}(\mathrm{~m}:$ 体重 $[\mathrm{kg}] 1$ : 身長 $[\mathrm{cm}])$ を使用した。 $A=0.008883 * m^{0.444} * l^{0.663}$

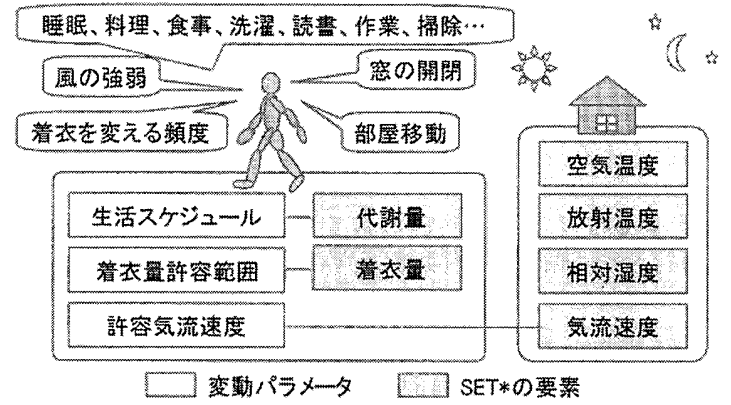

図 1.SET*の要素と居住者の条件による変動パラメータの関係

表 1. ASHRAE 快適範囲と変動快適範团の要件

\begin{tabular}{|c|c|c|c|c|}
\hline ASHRAE & 夏季 & 冬季 & \multicolumn{2}{|c|}{ 本研究変動快適範囲 } \\
\hline$E T^{*}$ & $22.5-26$ & $20-23.5$ & SET & $21.53-25.23$ \\
\hline  & \multicolumn{2}{|c|}{1.1} & 代謝量 MET & 居住者の生活スケジュール \\
\hline 着衣量 clo & 0.5 & 0.9 & 着衣量 do & 居住者の着衣量吘容範囲 \\
\hline 受流速度 $\mathrm{m} / \mathrm{s}$ & \multicolumn{2}{|c|}{0.15} & 気流速度 $\mathrm{m} / \mathrm{s}$ & ఏ 居住者の鼓容気流速度 \\
\hline 湿球温度 ${ }^{\circ} \mathrm{C}$ & $\leqq 20$ & $\leq 18$ & 相対湿度 \% & $\leqq 90$ \\
\hline 露点温度 ${ }^{\circ} \mathrm{C}$ & \multicolumn{2}{|c|}{$2.0 \leq$} & 湿球温或 ${ }^{\circ} \mathrm{C}$ & $\leqq 20$ \\
\hline & & & 露点温度 ${ }^{\circ} \mathrm{C}$ & $2.0 \leqq$ \\
\hline \multicolumn{5}{|c|}{ ET"快適域（ASHRAE） } \\
\hline & 目的 & \multicolumn{3}{|c|}{ 居住者の条件により変化させるため } \\
\hline \multicolumn{5}{|l|}{ SET“仭適域 } \\
\hline & 自的 & \multicolumn{3}{|c|}{ 設計者およひ居住者自身の理鯶·俨価を容易にするため } \\
\hline \multicolumn{3}{|c|}{ 空気温度快適域 } & \multicolumn{2}{|c|}{ 居住者の条件による变動枎適籍囲 } \\
\hline
\end{tabular}

図 2. 变動快適範囲への変換手順

表 2. 計算範囲と計算間隔

\begin{tabular}{|c|c|c|c|c|}
\hline & & 計算範聿 & & 計算間隔 \\
\hline 空复温度 & ${ }^{\circ} \mathrm{C}$ & $10 \sim 40$ & 0.2 & \\
\hline 故射温度 & ${ }^{\circ} \mathrm{C}$ & =空気温度 & 0.2 & \\
\hline 相対湿度 & $\%$ & $10 \sim 90$ & 5.0 & \\
\hline 㲷流速度 & $\mathrm{m} / \mathrm{s}$ & $0.1 \sim 1.0$ & 0.1 & \\
\hline 着衣量 & clo & $0.3 \sim 1.2(3.0)$ & 0.1 & 冬季睡眠時 : 3.0 \\
\hline 伐謝量 & Met & $0.8 \sim 2.2$ & & 表了参照 \\
\hline 大氮压 & $\mathrm{kPa}$ & 101,325 & & 固定 \\
\hline
\end{tabular}

表 3. 生活行為と代謝䚓の関係

\begin{tabular}{|c|c|c|c|c|c|}
\hline MET & 生活行為 & MET & 生活行為 & MET & 生活行為 \\
\hline \multirow{2}{*}{0.8} & 睡眠 & \multirow{4}{*}{1.2} & 勝負ごと & \multirow{7}{*}{2.0} & 勰除 \\
\hline & 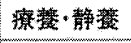 & & 趣味 & & 洗滥干し:取入れ \\
\hline \multirow{7}{*}{1.0} & 在宅 & & テレビ & & 社会参加 \\
\hline & 家族対話 & & ラジオ & & 仕事つきあい \\
\hline & 新聞 & 1.4 & 食事 & & 行楽·散策 \\
\hline & 雑誌 & \multirow{4}{*}{1.6} & 洗顔 & & スポーツ \\
\hline & 本 & & 普がぞ & & けいこことと \\
\hline & マンガ & & 洗灌 & 2.2 & 粎事 \\
\hline & 無行為 & & アイロンがけ & & \\
\hline 1.2 & 学䔝 & 2.0 & 入浴 & & \\
\hline
\end{tabular}

表 4 に検討を行ったASHRAEの標準人と日本人における年齢別の 身長·体重・体表面積·基礎代謝量、ET*快適域を 2.3 の方法により変 換した SET*快適域を示す。年齢が高くなるとともに SET*快適域の 下限は下がり、上限は高くなるが、その差はわずかである。そのた め今後の解析では人の条件による違いは考慮せず、ASHRAE の標準 人を対象とし、SET*快適域：21.58 25.23 $\left.{ }^{\circ} \mathrm{C}\right]$ を用いることとした。 


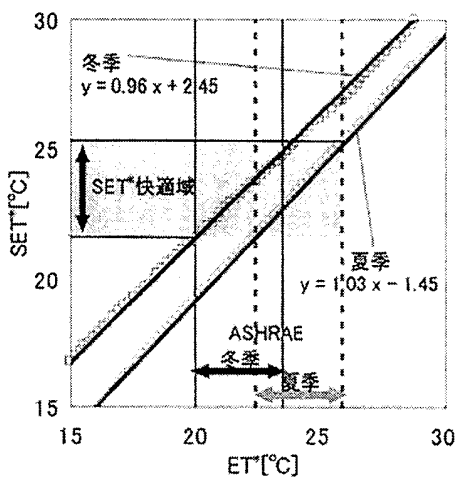

図 3. $E T^{*}$ 快適域 $\rightarrow \mathrm{SET}^{*}$ 快適域
表 4. 生活行為と代謝量の関係

\begin{tabular}{|c|c|c|c|c|c|c|c|c|c|c|c|c|}
\hline \multirow{3}{*}{$\begin{array}{l}\text { 年龄 } \\
\text { (墄) }\end{array}$} & \multirow{2}{*}{\multicolumn{2}{|c|}{ 身長 $[\mathrm{cm}]$}} & \multirow{2}{*}{\multicolumn{2}{|c|}{ 体重 $[\mathrm{kg}]$}} & \multirow{2}{*}{\multicolumn{2}{|c|}{$\begin{array}{c}\text { 体表面積 } \\
{\left[\mathrm{m}^{2}\right]}\end{array}$}} & \multirow{2}{*}{\multicolumn{2}{|c|}{$\begin{array}{c}\text { 基礎代竧量 } \\
{\left[\mathrm{W} / \mathrm{m}^{2}\right]}\end{array}$}} & \multicolumn{4}{|c|}{$\mathrm{SET}^{*}$} \\
\hline & & & & & & & & & \multirow{2}{*}{\begin{tabular}{|c|} 
下限 \\
男
\end{tabular}} & \multirow{2}{*}{ 上限 } & \multirow{2}{*}{$\begin{array}{c:}\text { 下限 } \\
\text { 女 }\end{array}$} & \multirow{2}{*}{ 上限 } \\
\hline & 男 & 女 & 男 & 女 & 男 & 女 & 男 & 女 & & & & \\
\hline 標準 & & & \multicolumn{2}{|c|}{70.0} & \multicolumn{2}{|c|}{1.8} & \multicolumn{2}{|c|}{58.2} & 21.58 & 25.23 & & \\
\hline $1-2$ & \multicolumn{2}{|c|}{83.6} & \multicolumn{2}{|c|}{11.5} & \multicolumn{2}{|c|}{0.5} & 68.6 & 67.1 & 21.58 & 25.15 & 21.59 & 25.16 \\
\hline $3-5$ & \multicolumn{2}{|c|}{102.3} & \multicolumn{2}{|c|}{16.4} & \multicolumn{2}{|c|}{0.7} & 65.7 & 62.6 & 21.59 & 25.17 & 21.60 & 25.19 \\
\hline $6-8$ & 121.9 & 120.8 & 24.6 & 23.9 & 0.9 & 0.9 & 59.2 & 55.4 & 21.59 & 25.21 & 21.57 & 25.23 \\
\hline $9-11$ & 139.0 & 138.4 & 34.6 & 33.8 & 1.1 & 1.1 & 55.4 & 51.0 & 21.57 & 25.23 & 21.56 & 25.25 \\
\hline $2-14$ & 158.3 & 153.4 & 47.9 & 45.3 & 1.4 & 1.4 & 50.5 & 47.7 & 21.56 & 25.25 & 21.55 & 25.26 \\
\hline $5-17$ & 169.3 & 157.8 & 59.8 & 51.4 & 1.6 & 1.5 & 47.6 & 42.9 & 21.54 & 25.27 & 21.53 & 25.29 \\
\hline |8-29: & 171.3 & 158.1 & 64.7 & 51.2 & 1.7 & 1.5 & 43.8 & 39.9 & 21.53 & 25.28 & 21.52 & 25.30 \\
\hline $30-49$ & 169.1 & 156.0 & 67.0 & 54.2 & 1.7 & 1.5 & 41.9 & 38.2 & 21.53 & 25.29 & 21.52 & 25.31 \\
\hline 50-69 & 163.9 & 151.4 & 62.5 & 53.8 & 1.6 & 1.5 & 39.7 & 37.0 & 21.52 & 25.30 & 21.52 & 25.32 \\
\hline $70-$ & 159.4 & 145.6 & 56.7 & 48.7 & 1.5 & 1.4 & 38.3 & 36.0 & 21.52 & 25.31 & 21.52 & 25.32 \\
\hline
\end{tabular}

\subsubsection{SET*快適域から空気温度快適域への変換}

図 4 に相対湿度 : $50[\%]$ 、代謝量 : $1.0[\mathrm{Met}] \cdot 1.6[\mathrm{Met}] \cdot 2.2[\mathrm{Met}]$ 、 気流速度 : $0.1[\mathrm{~m} / \mathrm{s}]$ 、着衣量 : 0.6[clo]の場合を例として、表 2 の計 算条件で算出した SET*/空気温度の散布図とその近似直線を示す。 近似直線が $\mathrm{SET} *$ 快適域の籁囲内となる空気温度を空気温度快適域 とした。同様に変動パラメータごとに表 2 に示す計算範囲と計算間 隔で空気温度快適域への変換を行った。

\subsection{4. 空気温度快適域から变動快適範囲への変換}

図 4 で求めた空気温度快適域に表 1 に示した湿度条件を付加し、 変動快適範囲を作成した。図 5 の a)b)は代謝量、着衣量は同じ条件 であるが、気流速度が a) $1.0[\mathrm{~m} / \mathrm{s}] 、$ b) $0.1[\mathrm{~m} / \mathrm{s}]$ と異なる。b) $1.2[\mathrm{clo}$ と c)は着衣量、気流速度は同じ条件であるが、b)は 1.0[MET]であり、 c)は $0.8[\mathrm{MET}]$ と $2.2[\mathrm{MET}]$ を示す。d)には変動快適範囲の可動域と冬 季(1 3 月、10 12 月)睡眠時の下限を示す。表 2 に示すように、冬季 の睡眠時は布団を考慮して着衣量 3.0[clo]とするため、変動快適範囲 の可動域より下限が広がる。これらの図から、変動快適籁囲をクリ モグラフ上に示すことで、居住者の条件(代謝量、気流速度、着衣量) による変化が明快になることがわかる。

\section{3. 温熱性能評価方法}

図 6 に本研究で提案する温熱性能評価方法のフロー図を示す。本 評価方法では建物の温熱性能を評価するために、まずシミュレーシ ヨン・実測によって室環境(空気温度、相対湿度、気流速度)を算出す る。算出した各室環境を各居住者の生活スケジュールをもとに時間 軸に沿って合成し、各居住者の曝露環境(空気温度、相対湿度、気流 速度)を合成する。合成した時間軸を持つ曝露環境を各居住者の生活 スケジュールによる代謝量と、環境調整行動(着衣量許容範囲·許容 気流速度)をパラメータとした前章で作成した居住者の条件による変 動快適範囲により評価する。評価は、在宅時間中にどの程度快適な 時間があるか、どの程度曝露環境が変動快適範囲から離れているか により行う。各居住者の曝露環境が快適範囲内の場合は在宅時間中 の快適時間率(以後 $\mathrm{CH}$ )、快適範囲外の場合は快適範囲と曝露環境亡 の温度差(以後 TD)を算出する。月ごとに各時間について平均 $\mathrm{CH}$ 、 $\mathrm{TD}$ を算出し、12 ケ月分時間軸に沿って並べる。これを各月時間平 均 $\mathrm{CH} 、 \mathrm{TD}$ とし、居住者の条件、生活スケジュールと比較しながら 年間の曝露環境評価の変動を詳細にみることが可能となる。評価条 件の違いによる比較を行う場合には、年平均 $\mathrm{CH}$ 、月平均 $\mathrm{CH}$ の変動、 年最大、最小、月平均 TD の変動を示す。

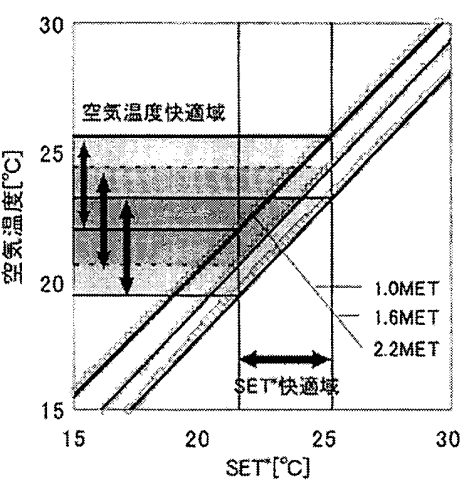

図 4. SET*快適域 $\rightarrow$ 空気温度快適域 相対湿度 : $50[\%]$ 代謝量 : $1.0 \cdot 1.6 \cdot 2.2[\mathrm{Met}]$ 気流速度 : $0.1[\mathrm{~m} / \mathrm{s}]$ 着衣量 : $0.6[\mathrm{c} \mid 0]$
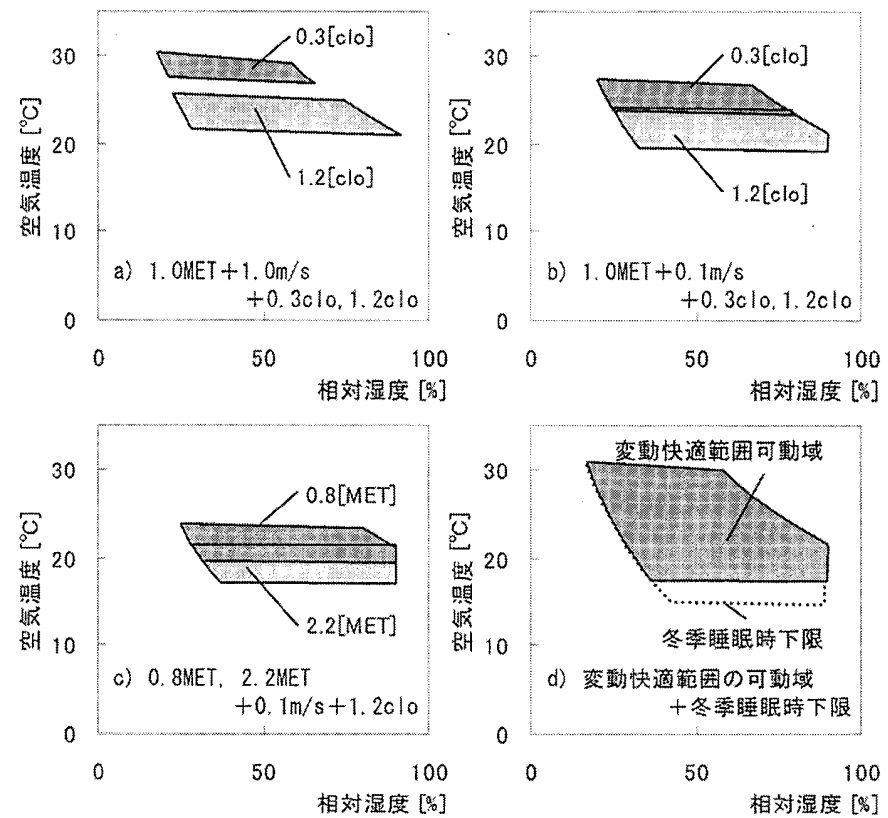

図 5. 変動快適範囲の例

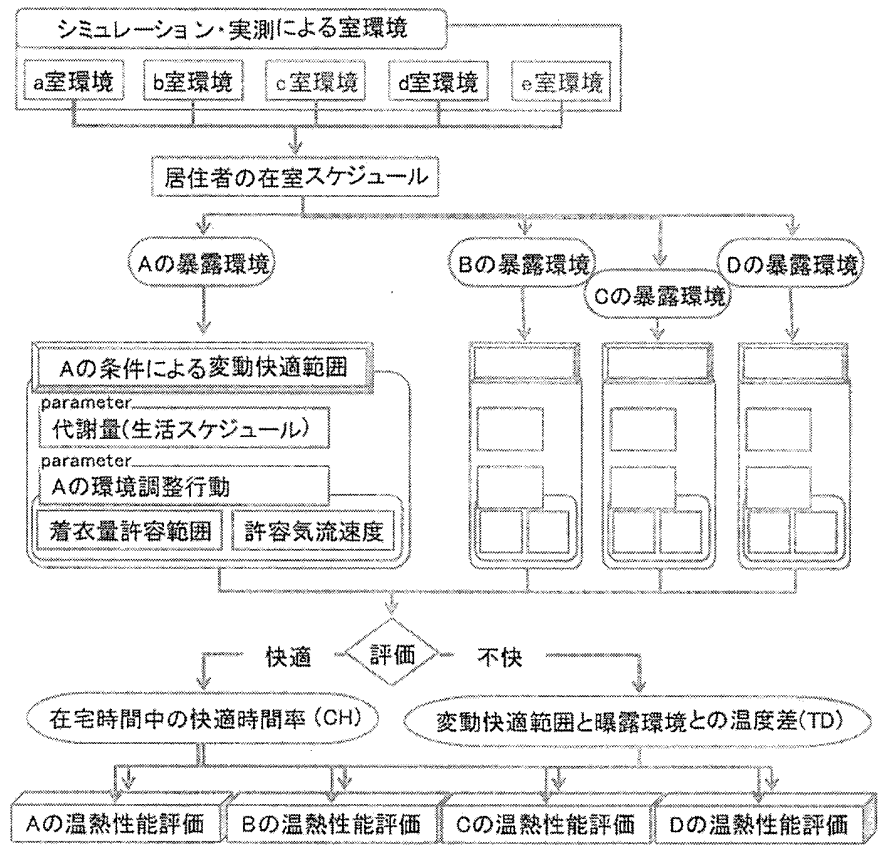

図 6. 温熱性能評価方法のフロー図 


\section{4. 温熱性能評価事例}

\section{1. 計算概要}

\subsection{1. 対象地点と気象データ}

対象地点は, 次世代省エネルギ一基準 ${ }^{14)} \mathrm{IV}$ 地域で, 暖房デグリ一 デーが平均值に近く、人口の多い府中市とした。気象データには METEONORM ver. $5.0^{15)}$ による付中市データ ( 1 時間間隔)を使用した。

\subsection{2. 対象建物}

日本建築学会標準問題の戸建住宅モデル ${ }^{16)}$ を対象とした。図 7 に 対象住宅の平面図、表 5 に各部位の構成を示す。断熱性能は次世代 基淮 $^{14)}$ の気候区分による木造充填工法に準ずる。表 6 にIV地域にお ける断熱分類 C (グラスウール 32K を想定)の厚さを示す。

\subsection{3. 計算方法}

シミュレーションプログラムは多数室動的熱負荷計算プログラム TRNSYS と多数室換気量計算プログラム COMIS を連成させ、全居 室の非空調状態での室内温熱環境を 1 時間間隔で計算した。居住者 の環境調整行動を考慮した温熱性能評価をするためには室内気流速 度を算出する必要がある。しかし、TRNSYS-COMIS では室内気流 速度は直接計算されず、室換気量と外気導入量が算出される。そこ で、図 8 に示すように、各室換気量と外気導入量から室内空気流量

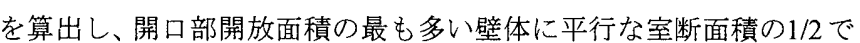
除したもの ${ }^{18)}$ を室内気流速度として換算した。家族構成は勤め人、 家庭婦人、中学生、小学生の 4 人とし、熱発生スケジュールは空気 調和·衛生工学会の住宅用標準スケジュール $\left.{ }^{10)}{ }^{11}\right)$ (15 分間隔)を用いた。 4.1.4. 計算条件

表 7 に計算モードと評価条件を示した。環境調整行動(開口部開閉 の有無)の違いを検討するため、計算モードは空と室内外の扉も含む 開口部の自然換気 $\left(\right.$ 外気温度 $20\left[{ }^{\circ} \mathrm{C}\right]$ 以上の時開口部開放 $\left.{ }^{17)}\right)$ の有無に よる開口部常時閉鎖と開口部開閉の 2 モードとした。評価対象人は 在宅時間の短い勤め人と長い家庭婦人とした。また、評価条件は、 着衣量許容範囲が 0.5 0.9[clo]の場合と 0.3 1.2[clo]の場合の評価、い ずれも許容気流速度は上限 $1.0[\mathrm{~m} / \mathrm{s}]$ とした。計算 2 モードと 4 条件 を合わせて、計 8 条件の評価を行った。

\section{2. 居住者曝露環境の作成}

図 9 に開口部開閉モードにおける室環境の例として左図に居間の 室温/相対湿度の散布図とクリモグラフ、右図に室内気流速度の時変 動を示す。図 10 に勤め人の生活スケジュール(1 日の活動代謝量と 居室)を、図 11 に家庭婦人の生活スケジュールを示す。図 10、11の

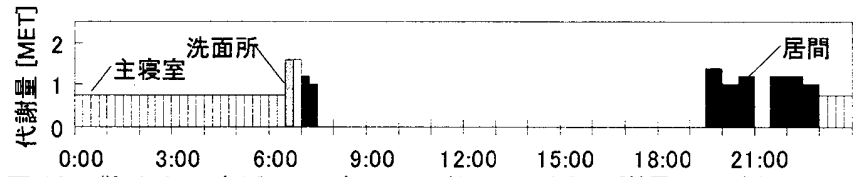

図 10. 勤め人の生活スケジュール (1 日の活動代謝量と居室)
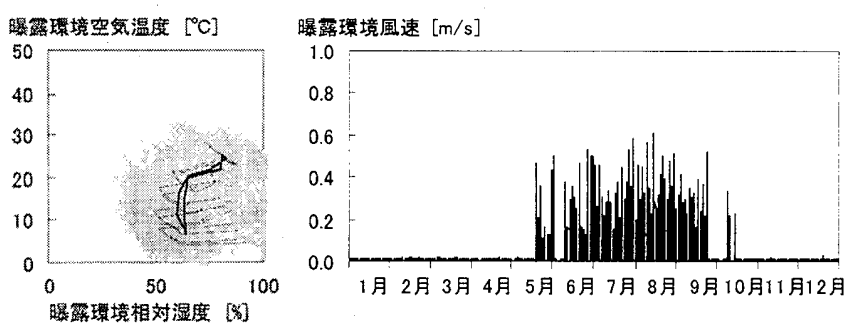

図 12. (左) 曝露環境空気温度/相対湿度散布図とクリモグラフ （右）曝露環境風速時変動 [勤め人）(開口部開閉モード）

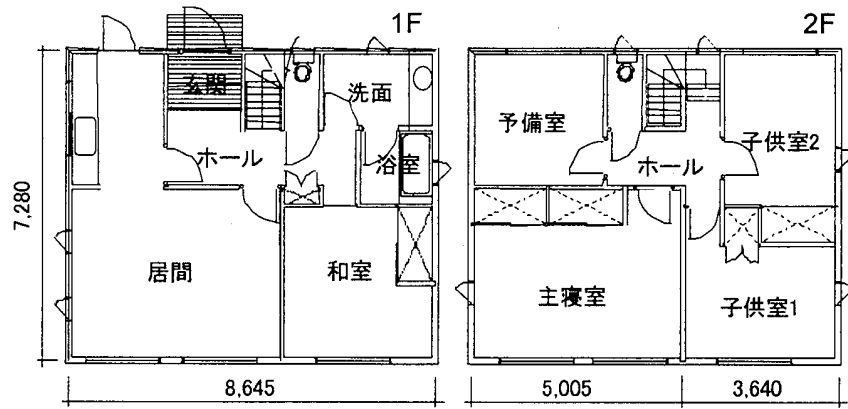

図 7. 日本建築学会標準問題の戸建住宅モデル平面図 表 5. 対象建物各部位の構成

\begin{tabular}{|c|c|}
\hline 部位 & 構成 \\
\hline 外壁 & モルタル $(30 \mathrm{~mm}) /$ 合板 $(9 \mathrm{~mm}) /$ 空気層/断熱材/石亳ボート $(12 \mathrm{~mm})$ \\
\hline 内壁 & 石鲁ボード(12mm)/空気層/石亮ボード(12mm) \\
\hline 屋根 & スL-ト $(12 \mathrm{~mm}) /$ 合板 $(12 \mathrm{~mm}) /$ 空気層/断熱材/石亳ボ-ド $(12 \mathrm{~mm})$ \\
\hline 1F床 & 床板 $(10 \mathrm{~mm}) /$ 合板 $(12 \mathrm{~mm}) /$ 断熱材 \\
\hline 2F床 & 力-ペット (15mm)/合板 $(12 \mathrm{~mm}) /$ 空気層/断熱材/石亳ボ・ド $(12 \mathrm{~mm}$ \\
\hline 悹 & 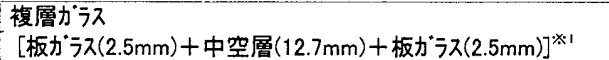 \\
\hline
\end{tabular}

表 6. 断熱厚さ (IV地域) 部位 厚さ 部位 [mm] 屋根 160 天井 160 \begin{tabular}{l|l}
\hline 壁 & 90 \\
\hline 床 & 90
\end{tabular} (multi-zone building)Version 4.0, TRANSSOLAR Energietechnik GmbHIELろ



図 8. 室内気流速度の計算方法

表 7. 計算モードと評価条件

\begin{tabular}{|c|c|c|c|c|c|c|c|c|}
\hline \multirow{2}{*}{$\begin{array}{l}\text { 条件 } \\
\text { 計算モード }\end{array}$} & A & $B$ & C & D & $\mathrm{E}$ & $F$ & G & $\mathrm{H}$ \\
\hline & \multicolumn{4}{|c|}{ 開口部常時閉銷 } & \multicolumn{4}{|c|}{ 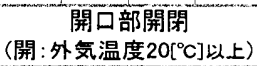 } \\
\hline 対象人 & \multicolumn{2}{|c|}{ 勤め人 } & \multicolumn{2}{|c|}{ 家庭婦人 } & \multicolumn{2}{|c|}{ 勤め人 } & \multicolumn{2}{|c|}{ 家庭婦人 } \\
\hline \multirow{3}{*}{ 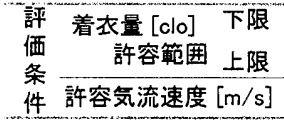 } & 0.5 & 0.3 & 0.5 & 0.3 & 0.5 & 0.3 & $\underset{\sim}{0.5}$ & 0.3 \\
\hline & $\tilde{0.9}$ & 1.2 & $\tilde{0.9}$ & $\tilde{1.2}$ & $\tilde{0.9}$ & $\tilde{1.2}$ & $\tilde{0.9}$ & $\tilde{1.2}$ \\
\hline & \multicolumn{8}{|c|}{$\sim 1.0$} \\
\hline 室温 [ $\left.{ }^{\circ} \mathrm{C}\right]$ & \multicolumn{8}{|c|}{ 室内気流速度 $[\mathrm{m} / \mathrm{s}]$} \\
\hline 10 & 0.8 & & & & & & & \\
\hline 4 & 0.6 & & & & & & & \\
\hline dits & 0.4 & & & & & & & \\
\hline$t^{2}$ & 0.2 & & & & & & & \\
\hline $\begin{array}{lll}0 & 50 & 100 \\
& & \text { 相対湿度 }\end{array}$ & & & & & & & & \\
\hline
\end{tabular}

図 9.（左）室温/相対湿度散布図とクリモグラフ

(右) 室内気流速度時変動 [居間] (開口部開閉モード)

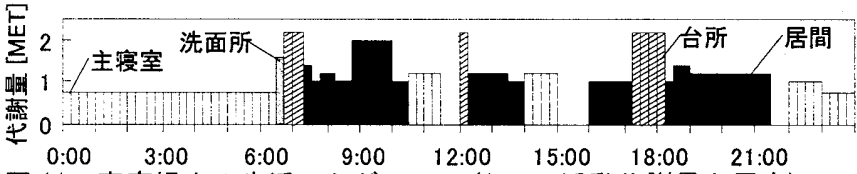
図 11. 家庭婦人の生活スケジュール(1 日の活動代謝量と居室)
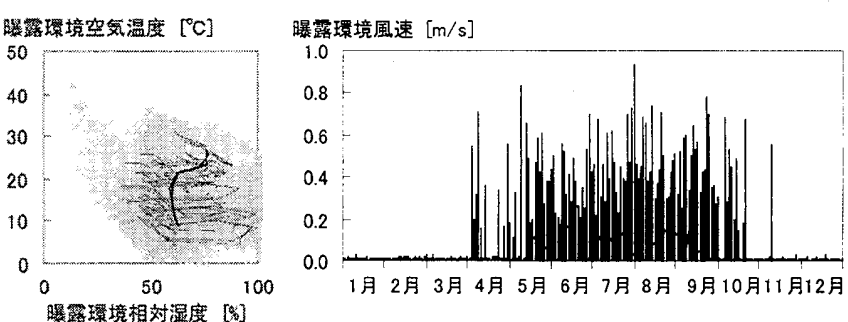

13. (左) 曝露環境空気温度/相対湿度散布図とクリモグラフ （右）曝露環境風速時変動 [家庭婦人](開口部開閉モード) 


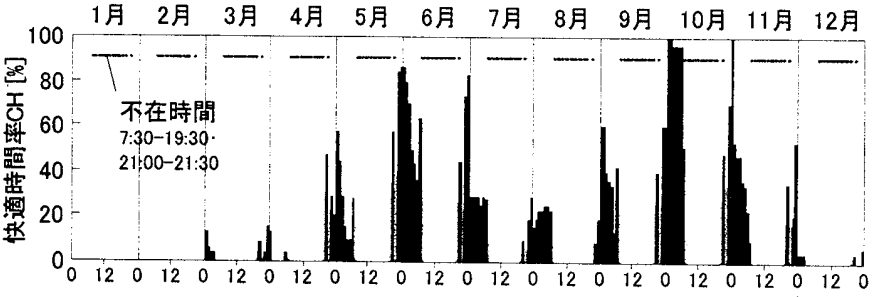

図 14. 条件 $\mathrm{E}$ の各月時間平均快適時間率 $(\mathrm{CH})$ [勤め人]

（開口部開閉モード・着衣許容範囲 0.5 0.9[c/o]·許容気流速度 $1.0[\mathrm{~m} / \mathrm{s}]$ )



$\begin{array}{llllllllllllllllllllllll}-16 & 12 & 0 & 12 & 0 & 12 & 0 & 12 & 0 & 12 & 0 & 12 & 0 & 12 & 0 & 12 & 0 & 12 & 0 & 12 & 0 & 12 & 0 & 12\end{array}$ 図 15. 条件 $\mathrm{E}$ の各月時間平均温度差 (TD) [勤め人]

(開口部開閉モード·着衣許容範国 $0.5 \sim 0.9[\mathrm{clo}] \cdot$ 許容気流速度 $1.0[\mathrm{~m} / \mathrm{s}]$ )

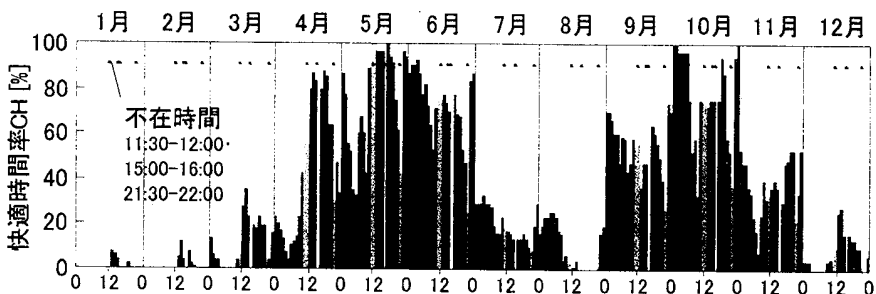

図 16. 条件 $\mathrm{H}$ の各月時間平均快適時間率 $(\mathrm{CH})$ [家庭婦人]

（開口部開閉モード·着衣許容範囲 $0.3 \sim 1.2[\mathrm{clo}$ ·許容気流速度 $1.0[\mathrm{~m} / \mathrm{s}]$ )

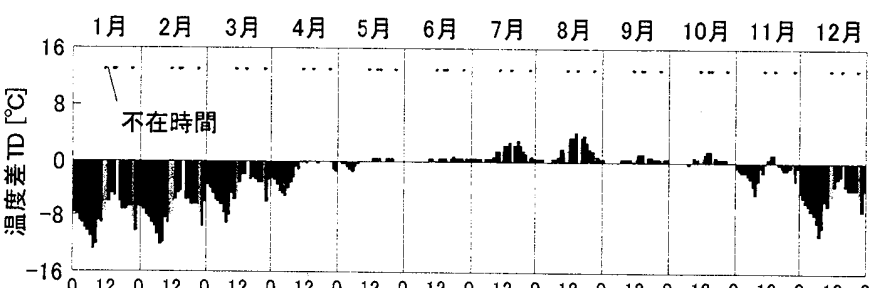

図 17. 条件 H の各月時間平均温度差 (TD) [家庭婦人]

（開口部開閉モード·着衣許容範囲 $0.3 \sim 1.2[\mathrm{clo}$ ] 許容気流速度 $1.0[\mathrm{~m} / \mathrm{s}]$ )
ような各居住者の生活スケジュールに沿って、各人が過ごす室の室 環境(室温・相対湿度・気流速度)を合成し、時間軸を持つ曝露環境(15 分間隔)を作成する。ただし、入浴時はスケジュールから除外し、不 在時間扱いとする。図 12 に開口部開閉モードのときの勤め人の曝露 環境として、左図に曝露環境空気温度/相対湿度の散布図とクリモグ ラフ、右図に曝露環境風速の時変動を示す。同様に図 13 に家庭婦人 の曝露環境を示す。家庭婦人の曝露環境空気温度に比べ、昼間不在 の勤め人の曝露環境空気温度は低くなり、勤め人の曝露環境風速の 方が小さい。このような各居住者の曝露環境を各条件による変動快 適範囲で評価することで、居住者自身のすごす環境を評価できる。

\section{3. 温熱性能評価結果}

\subsection{1 詳細評価例}

図 14 に条件 $\mathrm{E}$ (開口部開閉モード| 勤め人 | 着衣許容範囲 $0.5 \sim 0.9$ [clo] 許容気流速度 $1.0[\mathrm{~m} / \mathrm{s}])$ の各月時間平均快適時閒率 $(\mathrm{CH})$ 、図 15 に各月時間平均温度差 (TD) を示す。起床時間中では 5 月 22 時(TV) の CH が 83.9[\%]と最も高く、6.9・10月の 22 時、6.10月の 6 時(起 床一-洗顔 着替え)も $\mathrm{CH}$ が 50[\%]以上と高い。しかし、8月 19 21 時(帰宅 $\rightarrow$ 食事 $\rightarrow$ 新聞 $(\rightarrow 入$ 浴 $) \rightarrow \mathrm{TV})$ の $\mathrm{CH}$ は $0[\%]$ となる。また、冬 季 6 時の TD は起床時に布団から出るため着衣量の変化が大きく、1 月 6 時の $\mathrm{TD}$ は-12.3[ $\left.{ }^{\circ} \mathrm{C}\right]$ と非常に低い。夏季最高 TD は $3.3\left[{ }^{\circ} \mathrm{C}\right]$ であ るが、冬季最低 $\mathrm{TD}$ は-12.3 $\left[{ }^{\circ} \mathrm{C}\right]$ であり、寒さ対策がより必要である といえる。特に $1 \cdot 2$ 月の $\mathrm{CH}$ は $0[\%]$ て常に TD $-5\left[{ }^{\circ} \mathrm{C}\right]$ 以下となる。

次に、図 16 に条件 $\mathrm{H}$ (開口部開閉モード| 家庭婦人 | 着衣許容範囲 $0.3 \sim 1.2[\mathrm{clo}]$ ·許容気流速度 $1.0[\mathrm{~m} / \mathrm{s}])$ の各月時間平均 $\mathrm{CH}$ 、図 17 に各 月時間平均 TD を示す。家庭婦人忙着衣量許容範囲も広く昼間在宅 するため、冬季にも快適時間が現れる。 4 月昼前 夜、5・6・10 月は $\mathrm{CH}$ が 50[\%]以上と高い。特に 4 月昼過ぎ 夕方、 5 月昼前 夕方、 5. 6 月就寝前、10月夕方は $\mathrm{CH}$ が $80[\%]$ 以上である。一方、夏季の昼 間、特に 8 月は $\mathrm{CH}$ が $0[\%]$ となる。朝 9 時(掃除)は代謝量が高いた め、夏季はその前後の時間より $\mathrm{CH}$ が低く、冬季は高い。 $\mathrm{TD}$ をみる と、8 月昼過ぎから夕方にかけての TD が $3\left[{ }^{\circ} \mathrm{C}\right]$ 以上と高く、最高 $\mathrm{TD}$ は 1.4 時(趣味)の $4.1\left[^{\circ} \mathrm{C}\right]$ となった。冬季 6 時(起床一洗顔 $\rightarrow$ 炊事)は布 団から出るために TD が急に低くなるが、条件 E の勤め人と同じ部 屋で過ごしているにもかか和らず、着衣量許容範囲の広い家庭婦人(条
件 H)の TD は-11.1 $\left[{ }^{\circ} \mathrm{C}\right]$ と勤め人の TD より $1.2\left[{ }^{\circ} \mathrm{C}\right]$ 高くなる。これは 冬季起床時に 1 枚羽織る効果がみられているといえるが、条件 $\mathrm{E} の$ 勤め人と同様、冬季の寒さ対策がさらに必要であることがわかる。

\subsection{2 評価条件の違いによる温熱性能評価の違い}

図 18 に勤め人の環境調整行動による温熱性能評価(年平均 $\mathrm{CH} \cdot$ 月 平均 $\mathrm{CH}$ 変動·年最大 $\mathrm{TD}$ ·年最小 $\mathrm{TD}$.月平均 $\mathrm{TD}$ 変動)を示す。まず 年平均 $\mathrm{CH}$ は、大きい方から順に $\mathrm{F}$ (開口部開閉·着衣量許容範囲 $0.3 \sim 1.2[\mathrm{clo}]$ ) : 33.6[\%]、B(開口部閉鎖·着衣量許容範囲 0.3 1.2[clo]) : $28.86[\%] 、 \mathrm{E}\left(\mathrm{F}^{\mathrm{O}}\right.$ 口部開閉·着衣量許容範囲 $0.5 \sim 0.9[\mathrm{clo}]$ ) : 27.4[\%]、 $\mathrm{A}($ 開口部開鎖・着衣量許容範囲 0.5 0.9[clo]) : 23.6[\%]と、開口部の開 閉よりも着衣量許容範囲を増やすことの方が効果的であることがわ かる。月平均 $\mathrm{CH}$ 変動をみると、昼間不在の勤め人の場合、 4.5 月 は着衣量許容範囲を広げた方が、7 9 月は開口部の開閉を行う方が

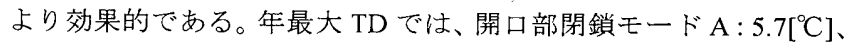
$\mathrm{B}: 4.7\left[{ }^{\circ} \mathrm{C}\right]$ であり、開口部開閉モード $\mathrm{E}: 0.8\left[{ }^{\circ} \mathrm{C}\right] 、 \mathrm{~F}: 0.4\left[{ }^{\circ} \mathrm{C}\right]$ となり、 開口部開閉による明確な差がみられる。年最小 $\mathrm{TD}$ に関しては詳細 評価例で示したように、冬季起床時が影響するため、着衣量許容範 囲の狭い $\mathrm{A} \cdot \mathrm{C}$ の TD が小さくなる。月平均 TD 変動をみると、開口 部開閉モードの $\mathrm{E} \cdot \mathrm{F}$ の方が夏季の TD が明らかに低い。

同様に、図 19 に家庭婦人の環境調整行動による温熱性能評価を示 す。年平均 $\mathrm{CH}$ は大きい方から順に、 $\mathrm{H}$ (開口部開閉・着衣量許容範囲 $0.3 \sim 1.2[\mathrm{clo}]): 34.8[\%] 、 G($ 開口部開閉·着衣量許容範囲 0.5 0.9[clo]) : $28.7[\%] 、 \mathrm{D}$ (開口部閉鎖·着衣量許容範囲 0.3 1.2[clo]) : 25.4[\%]、C(開 口部閉鎖·着衣量許容範囲 0.5 0.9[clo]) : 19.9[\%] と、環境調整行動の 多い G は、環境調整行動の少ない $\mathrm{C} よ り$ 倍近くの快適時間を得られ ることがわかる。また月平均 $\mathrm{CH}$ 変動をみても、開口部開閉モード の $\mathrm{G} \cdot \mathrm{H}$ が開口部閉鎖モードの C·D より常に $\mathrm{CH}$ が高い。環境調整 行動の多い $\mathrm{G}$ は、 $5 \cdot 6 \cdot 10$ 月には $80[\%]$ 近く快適な時間である。さら に、年最大 $\mathrm{TD} 、$ 月平均 $\mathrm{TD}$ 変動をみても、常に開口部開閉モードの TD の絶対值が小さいことがわかる。ただ、年最小 TDに関しては詳 細評価例で示したように、冬季起床時が影響するため、着衣量許容 範国の狭い D・Fの TD が小さくなる。

温熱性能評価は勤め人、家庭婦人同様に、環境調整行動の多い F. $\mathrm{H}$ が最も $\mathrm{CH}$ が高く、TD の絶詨値が小さい。特に夏季において開口 


\begin{tabular}{|c|c|c|c|c|c|c|c|}
\hline \multicolumn{4}{|c|}{ 評価条件 } & \multirow{3}{*}{$\begin{array}{l}\text { 計算 } \\
\text { モデル } \\
\text { 通風 }\end{array}$} & \multirow{3}{*}{$\begin{array}{l}\mathrm{CH} \\
\text { 年 } \\
\text { 平均 }\end{array}$} & \multicolumn{2}{|c|}{ TD } \\
\hline & & \multicolumn{2}{|c|}{ 着衣量 } & & & 年 & 年 \\
\hline & & 下限 & 上限 & & & 最大 & 最小 \\
\hline 勤 & $-\diamond \cdot A$ & 0.5 & 09 & \multirow{2}{*}{ x } & 23.6 & 5.7 & -9.5 \\
\hline$め$ & $\checkmark B$ & 0.3 & 1.2 & & 28.8 & 4.7 & -8.9 \\
\hline & $-0-E$ & 0.5 & 0.9 & \multirow{2}{*}{0} & 27. & 0.8 & -9.5 \\
\hline & $-F$ & 0.3 & 1.2 & & 33.6 & 0.4 & -8.9 \\
\hline
\end{tabular}
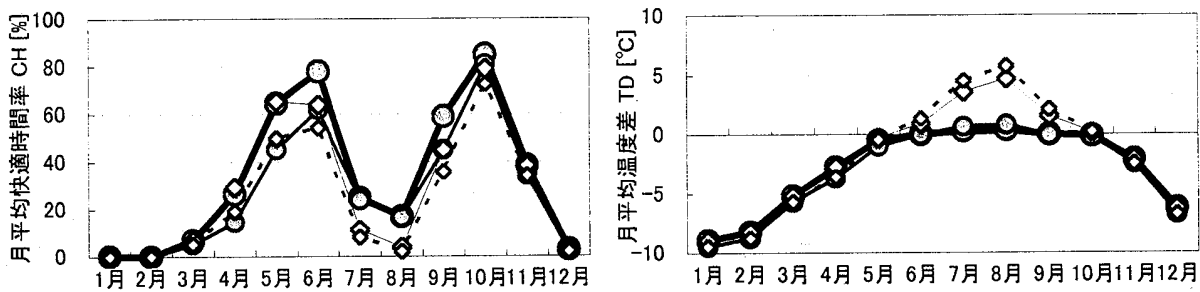

図 18. 勤め人の環境調整行動による温熱性

\begin{tabular}{|c|c|c|c|c|c|c|}
\hline \multirow[t]{3}{*}{ 評価条件 } & & & \multirow{3}{*}{ 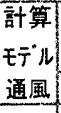 } & \multirow{3}{*}{$\begin{array}{c}\mathrm{CH} \\
\text { 年 } \\
\text { 平均 } \\
\end{array}$} & \multicolumn{2}{|c|}{ TD } \\
\hline & \multicolumn{2}{|c|}{ 着衣量 } & & & 年 & 年 \\
\hline & 下限 & 上限 & & & 最大 & 最小 \\
\hline 家 $-\diamond-c$ & 0.5 & 0.9 & & 19.9 & 7.6 & -9.0 \\
\hline 婦一一 D & 0.3 & 1.2 & & 25.4 & 6.4 & -8.2 \\
\hline 人 $-0 \mathrm{G}$ & 0 & 0.9 & \multirow{2}{*}{0} & 28.7 & 2.1 & -9 \\
\hline$\infty \mathrm{H}$ & 0.3 & 1.2 & & 34.8 & 1.4 & -8.2 \\
\hline
\end{tabular}


図 19. 家庭婦人の環境調整行動による温熱性能評価 (年平均 $\mathrm{CH}$ 月月平均 $\mathrm{CH}$ 变動·年最大 TD・年最小 TD·月平均 TD 変動)

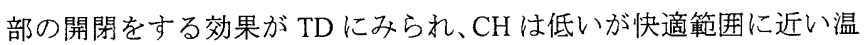
熱環境となっていることがわかる。冬季の寒さに対しては、建築手 法の増加、環境調整行動の増加により補ら必要がある。

\section{5. まとめ}

本研究では、居住者の条件により変動する快適範囲を示し、この 変動する快適範囲を使用した温熱性能評価方法を提案した。また、 戸建モデルを例に評価する居住者の条件を変えて温熱性能評価を行 い、提案した温熱性能評価方法の有効性を示した。以下に本研究に より得られた主な成果を示す。

1) ASHRAE の快適範囲から ET*快適域、SET*快適域、空気温度快 適域と変換し、条件を付加することで居住者の条件(代謝量·着衣量 許容範囲・許容気流速度)による変動快適範囲を作成した。ただし、 変動快適範囲は空気温度＝放射温度としており、また非定常条件で 使用するため、今後、被験者実験を行い、実際の温熱感評価と比較・ 検証する必要がある。

2) 上記の居住者の条件による変動快適範囲を用いて、被験者の環境 調整行動(開口部の開閉、着衣量による調整)を考慮しながら評価す る方法を提案した。

3) 居住者の生活スケジュールをもとに、多数室環境から時間軸に沿 って居住者の曝露環境を合成し、居住者ごとに作成した曝露環境を 評価することで、居住者自身のすごす環境を評価できるようにした。 4) 各居住者の曝露環境が快適範囲内の場合は在宅時間中にどの程度 快適な時間があるかを示す $\mathrm{CH}$ 、快適範囲外の場合はどの程度曝露 環境が変動快適範囲から離れているかを示す TD を算出した。各月 時間平均 CH、TD で示すことで居住者の条件生活スケジュールと比 較しながら年間の曝露環境評価の変動をみることを可能とした。

5) 評価条件の違いによる比較を年平均 $\mathrm{CH}$ 月月平均 $\mathrm{CH}$ 変動・年最大 $\mathrm{TD}$ 年最小 $\mathrm{TD}$ 月平均 $\mathrm{TD}$ 変動 TD で示した。今回の評価条件での 評価は、環境調整行動の多い方がより $\mathrm{CH}$ が高く、TDの絶対值が小 さくなったが、勤め人と家庭婦人それぞれの環境調整行動による効 果の違いが評価に現れた。

謝辞 本研究を進めるにあたり、SET*プログラムについては高田暁 先生(神戸大学)、TRNSYS-COMIS 計算については長谷川兼一先生(秋 田県立大学)にご指導いただきました。ここに記して深謝いたします。
参考文献

1）小林昌弘,中村卓司: 室内温熱感分布を考慮したペリメータゾーンの快適性と省 エネルギー評価方法の提案, 日本建築学会計画系論文報告集, NO. 510 , pp.69-75, 1998.8

2) 加藤信介,金泰延,村上周三: 対流・放射・湿度輸送と空調システム制御の連成 シミュレーション 第 1 報一作用温度一定条件での空調負荷の評価, 空気調和・ 衛生工学会論文集, NO.74, pp.81-88, 1999.7

3）山室寿行,藤永隆史,白石靖幸, 田辺新一,木村建一: スポット空調の熱的快適性

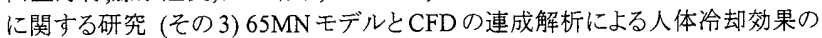
評価, 日本建築学会大会学術講演梗概集, D-2 分冊, pp.489-489, 2006

4) 大森敏明,田辺新一: 対流・放射連成シミュレーションによる室内温熱環境の総 合評価(その 2)人体温熱生理モデル JOS との連成, 日本建築学会大会学術講 演梗概集, D-2 分冊, pp.491-492, 2006

5) 鍵屋慎一,大森敏明,田辺新一:対流・放射連成シシュレーションによる窒内温熱 環境の総合評価(その3)人体温熱生理モデル JOSによる床暖房とエアコンの比 較, 日本建築学会大会学術講演梗概集, D-2 分冊, pp.493-494, 2006

6) 佐藤豊,郡公子,石野久彌: 自然室温による日本各地の戸建住宅の熱性能評価 に関する研究, 日本建築学会計画系論文報告集, NO.573, P41-46, 2003.11

7) ASHRAE : ASHRAE STANDARD, Thermal Environmental Conditions for Human Occupancy, 55a-1995

8）土川忠浩ほか:快適な温熱環境のメカニズム 豊かな生活環境をめざして，社 団法人空気調和・衛星工学会, 1997

9) 三浦豊彦ほか: 衣服と住まいの煡康学衣服と住まいの健康学 健康科学ライブ ラリー3, 大修館書店, 1997

10) 住宅用エネルギーシミュレーション小委員会:空気・調和・衛生工学会シンポジ ウム「住宅における生活スケジュールとエネルギー消費」: 社団法人空気調和・ 衛生工学会, 2000.3

11) 住宅用エネルギーシシュレーション小委員会: 生活スケジュール自動作成プログ ラム SCHEDULE ver.2.0, 社団法人空気調和·衛生工学会, 2000.3

12) 厚生保健医療局生活習慣病対策室: 第 6 次改定日本人の栄養所要量につい て-食事攝取基準-, 2000

13) 藤本蒠喜ほか: 栄盖学雑誌第 28 巻 6 号, 日本栄養改善学会, 1968

14) 次世代省エネルギー基準解説書編集委員会: 住宅の次世代省エネルギー基 準と指針，財団法人建築環境·省エネルギー機構, 1999

15) METEOTEST : METEONORM ver.5.0Global Meteorological Database for Engineers, Planners and Education, METEOTEST, 2003

16) 宇多川光弘: 第 15 回熱シンポジウム「電熱解析の現状と課題】標準問題の提案 住宅用標隻問題, 日本建築学会環境工学委員会, pp.23-33，1985

17) 佐々木寛,浦野良美,山崎均, 石井昭夫, 渡辺俊行, 林徹夫,龍有二,中田聡: 住宅 設計におけるパッシブクーリング性能予測, 日本建築学会大会学術講演梗概 集, D, pp.837-838, 1989

18) 宮本麻理子,須永修通,細井昭憲,権田努: O 郵便局における通風を利用した室 内気候調整システムに関する研究 その 4 省エネルギー効果の検討, 日本建 築学会大会学術講演梗概集, D-2 分冊, pp.595-596, 2004

19)深澤たまき,須永修通: 居住者の環境調整行動を考慮した温熱性能評価方法その 1 温熱性能評価方法の提案, 日本建築学会大会学術講演梗概集, D-2 分 冊, pp. 559-560, 2005

20)須永修通,深澤たまき: 居住者の環境調整行動を考慮した温熱性能評価方法その 2 建築学会標準問題を事例とした評価結果, 日本建築学会大会学術講 演梗概集, D-2 分冊, pp.561-562, 2005 